\title{
Testing the 'Fear of Floating' Hypothesis: A Statistical Analysis for Eight African Countries
}

\author{
Ahmad Hassan Ahmad ${ }^{1}$ - Eric J. Pentecost ${ }^{1,2}$
}

Published online: 20 December 2019

(C) The Author(s) 2019

\begin{abstract}
This paper revisits the fear of floating hypotheses for eight African countries from the collapse of the Bretton Woods fixed exchange rate system in the early 1970s up until December 2017. This long period of calendar time allows us to extend previous studies by examining the fear of floating hypotheses in two distinct ways. First, we look at a set of descriptive statistics to compare the degree of exchange rate flexibility under alternative de jure exchange rate regimes. We find no statistical difference between exchange volatility between declared floaters and fixers, but greater reserve volatility between the floaters, which is suggestive of fear of floating. Second, we use a non-linear, threshold VAR model, estimated for each country, to test for a relationship between exchange rate changes and reserve changes. The results suggest some evidence of a fear of floating for countries which have declared a de jure floating regime, with the regime-dependent impulse responses indicating that exchange rate appreciation due to positive reserve shocks is more prevalent in the high reserve regimes, indicative that level of foreign reserves available are important for their exchange rate policies. In general, although the countries with de jure floating regimes have a lower threshold than those with pegged regimes, reserves adjust by more than the exchange rates showing a fear of floating.
\end{abstract}

Keywords Exchange rates · International reserves $\cdot$ Fear of floating $\cdot$ Threshold VAR

JEL Classification F31 $\cdot \mathrm{F} 33 \cdot \mathrm{C} 22$

Ahmad Hassan Ahmad

A.H.Ahmad@lboro.ac.uk

Eric J. Pentecost

e.j.pentecost@ lboro.ac.uk

1 School of Business \& Economics Loughborough University, Loughborough, Leicestershire LE11 3TU, UK

2 Claremont Graduate University, Claremont, CA 91711, USA 


\section{Introduction}

In a perfectly floating exchange rate regime there should be no change in international reserves held by the central bank, whilst in a fixed exchange rate regime there should be no change in the exchange rate. In either 'perfect' regime there will be no relationship between the change in the nominal exchange rate and the change in the stock of international reserves. Therefore when a country declares a floating exchange rate regime and simultaneously reserves are changing it is suggestive of some intervention in the foreign exchange market to influence the level of the exchange rate. In this case we would expect to be able to identify a negative relationship between reserve changes and exchange rate changes, with reserves being depleted to prevent or at least slow the depreciation of the exchange rate. This negative relationship between reserve changes and exchange rate changes was initially dubbed 'fear of floating' by Calvo and Reinhart (2002), ${ }^{1}$ because developing countries seemed be more tolerant of volatility in international reserves, domestic interest rates and commodity prices than they were to exchange rate volatility.

For fear of floating to be a realistic possibility then the level of maintained reserves is critical if the authorities' are to be able to effectively intervene in the foreign exchange market. Throughout the 1990s international reserves as a share of GDP in developing countries was above that and rose faster than, the same ratio in advanced economies (Jeanne and Ranciere 2006). By 2005 the gap had closed a little, but on average developing countries ratio of international reserves to GDP was about $7 \%$ higher than that of advanced countries, most of whom had floating exchange rate regimes. Moreover, the authorities in developing countries intervene in their foreign exchange markets with large amounts of foreign currency relative to the level of market turnover, the money base, and the stock of the domestic bonds outstanding. ${ }^{2}$ Not only is the level of reserves an unlikely constraint, but according to the IMF (2001) intervention by developing countries could bring about a greater impact on the path of exchange rate than in the developed economies because the authorities in these countries do not sterilize their interventions. This has been confirmed by recent literature. For example, Montes and Ferreira (2019) not only found intervention in Brazil's exchange rate markets was significant, but also indicative of a 'fear of floating' in the country. The 'fear of floating' argument, however, contradicts Nogueira and León-Ledesma (2009) who contend that the apparent exchange rate interventions are not due to 'fear of floating', but are meant to achieve the inflation target objective of the central bank. In addition, Bleaney and Tian (2014), using regression analysis verified the exchange rate regimes of several countries and concluded that their results are consistent with the IMF classification. ${ }^{3}$

\footnotetext{
${ }^{1}$ See also Levy-Yeyati and Sturzenegger (2004) who also argue that the declared, de jure, exchange rate regime may not be the same as the de facto exchange rate regime.

${ }^{2}$ Guimarraes and Karacadag (2004) observe that foreign exchange rate interventions in developing and emerging countries are very frequent and large in size, while Neely (2007) asserts that authorities in developing countries still actively involved in foreign exchange interventions across regimes and sizes of the markets. Killeen et al. (2006) argue that it is the private sector not the public sector that absorbs the innovation in the foreign exchange order flow when the peg regime is credible.

${ }^{3}$ Issue of fear of floating has resurfaced even in developed countries after the financial crisis. The Economist (2009) runs a special report on that in its June 13th edition where the issue was discussed in context of Western European countries.
} 
Another important feature of foreign exchange rate interventions in developing countries is the position occupied by the central banks in developing countries (Chandavarkar 1996). Central banks in these countries buy and sell foreign exchange for a number of reasons, including support for the balance of payments and with the aim of influencing the exchange rate level or to dampen exchange rate volatility. ${ }^{4}$ On the whole, governments or their agencies in the developing economies are an important source of foreign exchange because of the relative large size of the government economy. It is also argued that the most important reason for governments in developing countries often participate in the foreign exchange market, is defending their exchange rate policy objectives. It was discovered that on a number of occasions, government of developing countries or their agencies borrow from abroad with the main purpose of defending their exchange rate policy and not to finance their fiscal deficits. Taylor (1981) identified this type of transaction in the foreign exchange market by the developing countries way back in the early 1980s.

In this paper we attempt to discover whether there is still evidence of a fear of floating in a number of African economies, some of which declare a de jure floating rate system, given their increased experience with floating regimes since the mid-1908s. In other words, we try to test the idea that the fear of floating identified in the 1990s was simply due to the central banks continuing to follow traditional policies that they used under the Bretton Woods system, possibly because they lacked confidence that floating exchange rates would be stable rates. A lack of evidence of a negative association between reserve changes and exchange rate changes may confirm a change of behaviour and increased confidence in international markets. On the other hand, further evidence of a fear of floating might suggest that our sample economies continue to value a stable currency over international reserve or commodity price stability. ${ }^{5}$ One reason for this may be their concerns with other macroeconomic developments such as currency crises and more recently, the growing stock of outstanding debt as 24 African countries now exceed the 55\% debt to GDP ratio advised as prudent by the IMF (Financial Times (FT) 2018; Onyekwena and Ekeruche 2019; Coulibaly et al., 2019). In our sample, only Ghana exceeds this threshold (with a debt to GDP a of about 70\%,) but both Kenya and South African are on the threshold. The paper uses a threshold VAR model where endogenously determined threshold is computed and the sample split into low and high regimes for each country. Consequently, the paper can determine in which of the regimes that fear of floating exists.

The rest of the paper is organised as follows. The next section discusses the data set and Section 3 uses some descriptive statistics to assess the validity of the fear of floating hypothesis in our sample of countries. Section 4 uses a threshold VAR model to examine the potential non-linear relationship between reserve changes and exchange rate changes. Section 5 concludes arguing that there is some evidence of a continuing fear of floating.

\footnotetext{
${ }^{4}$ These are in addition to their traditional roles as central banks.

${ }^{5}$ Refer to Deaton (1999) and Christensen (2016), among others, on importance of commodity prices to African countries.
} 


\section{The Data Set}

The data is taken from International Financial Statistics (IFS) with a monthly frequency, over the long time period from January 1970 until December 2017, for eight African countries: Algeria, Botswana, Ghana, Kenya, Morocco, Nigeria, South African and Uganda. The choice of countries was made to offer a large range of de jure exchange rate regimes, see Table 1, whilst excluding some of the least developed countries of the continent.

Table 2 presents some of the descriptive statistics on these eight countries over this 40 year time period on nominal exchange rates, foreign reserves, money stocks and interest rates. All nominal exchange rates exhibit large standard deviations, often over $40 \%$ of their means, although with no evidence of skewness or kurtosis. The nominal exchange rate series are all non-stationary, but their first differences reject the null hypothesis of non-stationary as shown by the row of ADF statistics.

The money supply and reserve series show similarly large variations over the sample, but like the exchange rate series there is no evidence of either skewness or kurtosis and the first difference of the series are stationary, as shown by the ADF test statistics. The levels of reserves are consistently higher in the second part of the sample, although the fluctuations are consistently higher in the first part of the sample, before 1988, the exceptions being Botswana and Ghana whose variations are much less marked between the two sections of the sample. It seems therefore that the move towards greater exchange rate flexibility in the last 1980s is associated with a higher level of nominal reserves, perhaps due to inflation, but less reserve volatility, perhaps suggesting that interventions are smaller with a more flexible exchange rate regime.

The interest rates series show the greatest variation of all the series. The variation is most extreme in Kenya, where the rate of interest ranges from $0.8 \%$ to $84 \%$ and exhibits both skewness and extreme kurtosis. For Uganda, a more typical example, the interest rate ranges from $6 \%$ to $55 \%$, but like all other countries exhibits no skewness or kurtosis. These large variations in interest rates, although in part a reflection of periods of high inflation is also likely to reflect monetary policy changes with a view to exchange management.

\section{Descriptive Statistical Analysis}

To examine the a priori case for fear of floating we initially follow Calvo and Reinhart (2002) and set out thresholds for nominal exchange rate and reserve changes to indicate the variation between de jure regimes. In the case of a fixed exchange rate, the monthly change in the log of the nominal exchange rate, $\Delta e_{t}$, should be close to zero and increase with the degree of flexibility. We chose two thresholds, $\pm 1 \%$, which reflects the band inside the Bretton Woods exchange rate system, and $\pm 2.5 \%$ range taken from the exchange rate mechanism (ERM) of the European Monetary System (EMS). We then use these relatively narrow bands to examine the frequency distribution of the change in the log of the nominal exchange rates where we expect to find that:

$$
\operatorname{Pr}(\Delta e< \pm 1 \%)<\operatorname{Pr}(\Delta e< \pm 2.5 \%)<\operatorname{Pr}(\Delta e<\text { floating })
$$


Table 1 Descriptive statistics

\begin{tabular}{|c|c|c|c|c|c|c|c|c|}
\hline $\begin{array}{l}\text { Sample Monthly } \\
1970-2017\end{array}$ & Algeria & Botswana & Ghana & Kenya & Morocco & Nigeria & South Africa & Uganda \\
\hline \multicolumn{9}{|c|}{ Exchange rate (log) } \\
\hline Mean & 1.423 & 0.811 & -0.347 & 1.917 & 1.109 & 1.752 & 0.870 & 2.873 \\
\hline Std dev & 0.621 & 0.405 & 1.364 & 0.430 & 0.122 & 0.912 & 0.382 & 1.204 \\
\hline Min & 0.644 & -0.026 & -3.542 & 0.985 & 0.695 & -0.178 & -0.023 & -1.015 \\
\hline Max & 2.155 & 1.454 & 1.507 & 2.572 & 1.330 & 2.672 & 1.429 & 3.781 \\
\hline Skew & -0.153 & -0.457 & -0.869 & -0.721 & -1.164 & -1.013 & -0.851 & -1.905 \\
\hline Kurt & -1.837 & -0.857 & -0.052 & -0.564 & 2.077 & -0.346 & -0.338 & 2.453 \\
\hline $\mathrm{ADF}$ & $-19.62 *$ & $-20.48^{*}$ & $-6.57^{*}$ & $-15.63 *$ & $-18.95^{*}$ & $-18.92^{*}$ & $-15.58 *$ & $-19.90^{*}$ \\
\hline \multicolumn{9}{|l|}{ Reserves (log) } \\
\hline Mean & 3.886 & 3.654 & 3.297 & 3.227 & 3.694 & 4.052 & 4.021 & 2.784 \\
\hline Std dev & 0.903 & 0.495 & 0.915 & 0.710 & 0.804 & 0.675 & 0.865 & 0.799 \\
\hline Min & 2.490 & 2.289 & 2.061 & 1.725 & 1.660 & 2.392 & 2.624 & 0.207 \\
\hline Max & 5.491 & 4.243 & 5.187 & 4.472 & 4.506 & 4.917 & 5.416 & 3.650 \\
\hline Skew & 0.494 & -1.376 & 0.596 & 0.033 & -1.013 & -0.379 & 0.010 & -0.701 \\
\hline Kurt & -1.160 & 0.855 & -0.978 & -1.162 & -0.343 & -1.346 & -1.516 & -0.892 \\
\hline $\mathrm{ADF}$ & $-2.95 *$ & -19.95 & $-16.62^{*}$ & $-12.90 *$ & $-16.98 *$ & $-12.00 *$ & $-25.78^{*}$ & $-15.69^{*}$ \\
\hline \multicolumn{9}{|c|}{ Money stocks (log) } \\
\hline Mean & 4.886 & 4.271 & 4.060 & 5.805 & 5.669 & 6.586 & 5.993 & 3.675 \\
\hline Std dev & 0.891 & 0.599 & 0.935 & 0.849 & 0.454 & 0.772 & 0.730 & 0.819 \\
\hline Min & 3.367 & 3.087 & 1.608 & 4.848 & 4.800 & 5.425 & 5.079 & 2.523 \\
\hline Max & 6.430 & 5.228 & 6.076 & 7.549 & 6.465 & 7.935 & 7.403 & 5.359 \\
\hline Skew & 0.011 & -0.132 & 0.280 & 0.558 & 0.065 & 0.221 & 0.324 & 0.579 \\
\hline Kurt & -1.211 & -1.177 & -0.307 & -1.131 & -1.187 & -1.351 & -1.349 & -0.999 \\
\hline $\mathrm{ADF}$ & $-10.25^{*}$ & $-7.01 *$ & $-19.80^{*}$ & $-19.80 *$ & $-3.80 *$ & $-5.54 *$ & $-14.27 *$ & $-3.70 *$ \\
\hline \multicolumn{9}{|l|}{ Interest rates $(\%)$} \\
\hline Mean & 5.586 & 10.868 & 19.969 & 11.922 & 5.291 & 13.023 & 9.924 & 22.049 \\
\hline Std dev & 1.308 & 2.634 & 9.685 & 9.426 & 1.959 & 3.723 & 4.970 & 10.893 \\
\hline Min & 4.000 & 5.750 & 10.500 & 0.830 & 3.000 & 6.000 & 3.750 & 5.990 \\
\hline Max & 8.500 & 15.500 & 45.000 & 84.670 & 8.500 & 26.000 & 21.850 & 55.000 \\
\hline Skew & 0.575 & 0.114 & 1.235 & 3.984 & 0.552 & 0.458 & 0.475 & 1.317 \\
\hline Kurt & -0.388 & -1.036 & 0.620 & 24.402 & -1.241 & 1.389 & -0.994 & 1.655 \\
\hline $\mathrm{ADF}$ & $-21.82 *$ & $-20.63 *$ & $-8.04 *$ & $-10.31 *$ & $-19.71 *$ & $-19.15^{*}$ & $-15.50 *$ & $-16.42^{*}$ \\
\hline
\end{tabular}

Key: ADF test statistic is for the null hypothesis of a unit root in the first difference of the series; so the rejection of the null (denoted by $*$ ) shows the time series is stationary in first difference

We construct a similar set of thresholds for reserve changes the results from which are shown in Tables 3, 4, and 5, which is split into three sections according to the de jure exchange rate regime.

What is noticeable from Tables 3,4 , and 5 is the similarity between the fixers and the floaters. In fact statistically there is no difference between the average exchange rate change per month under floating as under fixing, with t-values of 


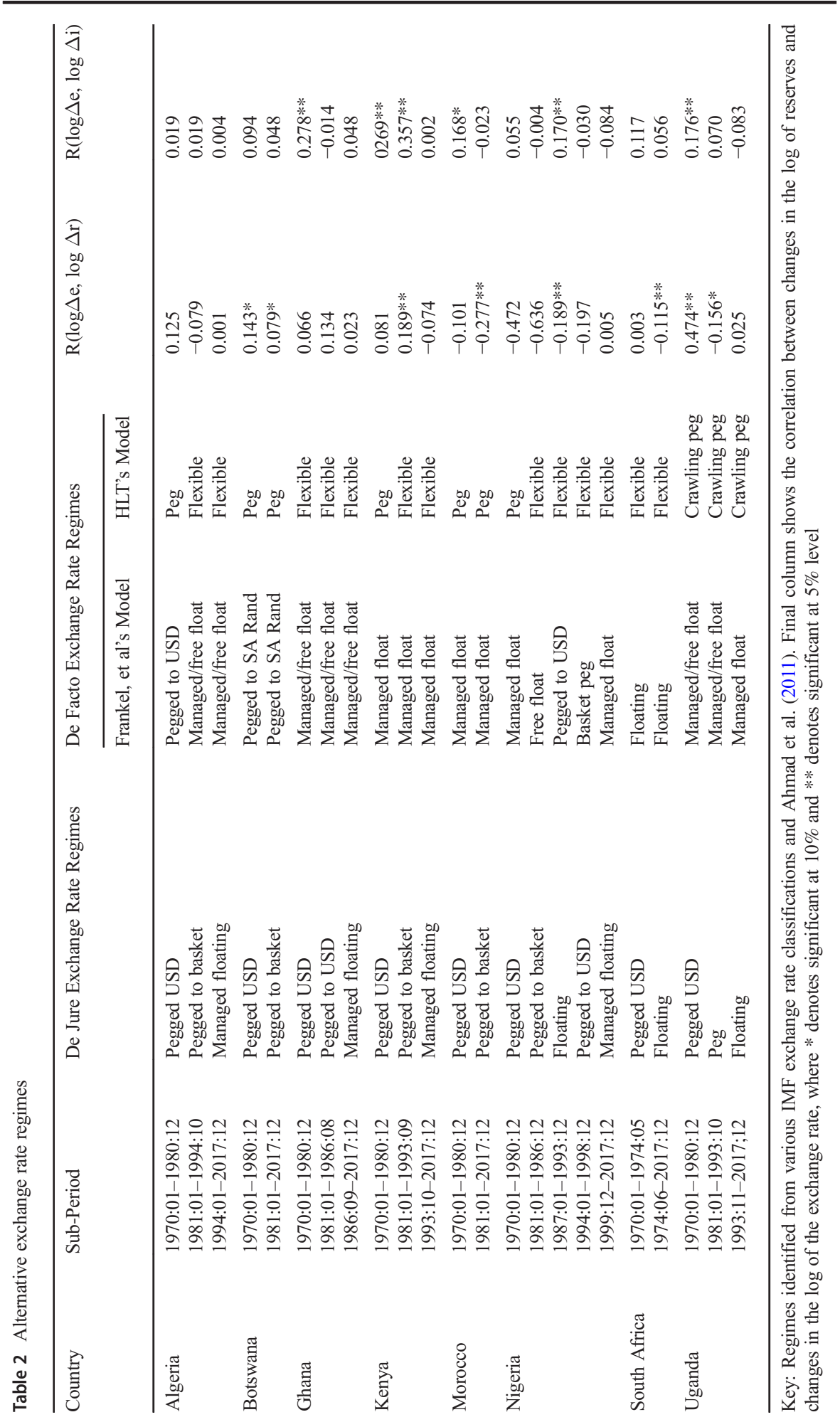


Table 3 By regimes: pegged to USD

\begin{tabular}{|c|c|c|c|c|}
\hline \multirow[t]{2}{*}{ Country and Periods Pegged to USD } & \multicolumn{2}{|c|}{$\begin{array}{l}\text { Probability that the monthly } \\
\text { percent change in the nominal } \\
\text { exchange rate falls within: }\end{array}$} & \multicolumn{2}{|c|}{$\begin{array}{l}\text { Probability that the monthly } \\
\text { percent change in foreign } \\
\text { exchange reserves falls within }\end{array}$} \\
\hline & $\pm 1 \%$ band & $\pm 2.5 \%$ band & $\pm 1 \%$ band & $\pm 2.5 \%$ band \\
\hline \multicolumn{5}{|l|}{ Algeria } \\
\hline 1970.01-1980.12 & 93.13 & 99.24 & 17.57 & 55.73 \\
\hline \multicolumn{5}{|l|}{ Botswana } \\
\hline 1970.01-1980.12 & 70.23 & 91.60 & 38.93 & 67.94 \\
\hline \multicolumn{5}{|l|}{ Ghana } \\
\hline 1970.01-1980.12 & 65.65 & 90.08 & 14.50 & 35.11 \\
\hline 1981.01-1986.08 & 71.76 & 93.89 & 57.25 & 68.70 \\
\hline \multicolumn{5}{|l|}{ Kenya } \\
\hline 1970.01-1980.12 & 85.50 & 96.95 & 17.56 & 41.22 \\
\hline \multicolumn{5}{|l|}{ Morocco } \\
\hline $1970.01-1980.12$ & 99.89 & 99.98 & 99.06 & 99.18 \\
\hline \multicolumn{5}{|l|}{ Nigeria } \\
\hline $1970.01-1980.12$ & 62.60 & 89.31 & 16.03 & 30.53 \\
\hline 1994.01-1998.12 & 88.14 & 98.31 & 25.42 & 66.10 \\
\hline \multicolumn{5}{|l|}{ South Africa } \\
\hline 1970.01-1974.05 & 84.31 & 100.00 & 41.18 & 19.61 \\
\hline \multicolumn{5}{|l|}{ Uganda } \\
\hline 1970.01-1980.12 & 51.15 & 79.39 & 7.63 & 10.79 \\
\hline Ave & 77.24 & 93.88 & 33.50 & 49.49 \\
\hline Med & 78.04 & 95.42 & 21.50 & 48.48 \\
\hline Std & 15.32 & 6.52 & 27.61 & 26.91 \\
\hline
\end{tabular}

0.8156 and 0.002 , for each of the bands, even if Algeria is excluded from the floating rate sample. For example, when Uganda declared a pegged regime the monthly percentage change in the exchange rate fell between the $1 \%$ and $2.5 \%$ bands $51 \%$ and $79 \%$ of the time. When it declared a floating regime from 1994 onwards, the monthly percentage change in the exchange rate fell between the same $1 \%$ and $2.5 \%$ bands $56 \%$ and $88 \%$ of the time, suggesting less exchange rate variation under floating. This is a priori evidence of fear of floating.

The difference between the two broad sets of exchange rate arrangements is in the behaviour of foreign exchange reserves. We would expect reserve changes to be smaller under floating than under fixed rates and this is confirmed by the data in Tables 3, 4, and 5 . Not only is the average monthly reserve change smaller under the floating and managed floating regimes, than under fixed regimes (both including and excluding Algeria), but the sample means are statistically significantly different from zero at $10 \%$ from the narrow band ( $\mathrm{t}$ values are -1.68 and -1.89 ) and at $5 \%$ for the $2.5 \%$ band $(\mathrm{t}$ values are -3.37 and -3.65 ). Thus it is the behaviour of the reserves that indicates the difference between the two main regimes. 
Table 4 Pegged to basket

\begin{tabular}{|c|c|c|c|c|}
\hline \multirow[t]{2}{*}{$\begin{array}{l}\text { Country and Periods } \\
\text { Basket pegs }\end{array}$} & \multicolumn{2}{|c|}{$\begin{array}{l}\text { Probability that the monthly } \\
\text { percent change in the nominal } \\
\text { exchange rate falls within: }\end{array}$} & \multicolumn{2}{|c|}{$\begin{array}{l}\text { Probability that the monthly } \\
\text { percent change in foreign } \\
\text { exchange reserves falls within: }\end{array}$} \\
\hline & $\pm 1 \%$ band & $\pm 2.5 \%$ band & $\pm 1 \%$ band & $\pm 2.5 \%$ band \\
\hline \multicolumn{5}{|l|}{ Algeria } \\
\hline 1981.01-1994.10 & 83.73 & 95.18 & 20.48 & 47.59 \\
\hline \multicolumn{5}{|l|}{ Botswana } \\
\hline 1981.01-2017.12 & 65.32 & 94.14 & 61.26 & 94.37 \\
\hline \multicolumn{5}{|l|}{ Ghana } \\
\hline 1986.09-2017.12 & 68.62 & 95.74 & 23.14 & 53.46 \\
\hline \multicolumn{5}{|l|}{ Kenya } \\
\hline 1981.01-1993.09 & 68.63 & 90.85 & 30.72 & 54.90 \\
\hline \multicolumn{5}{|l|}{ Morocco } \\
\hline 1981.01-2017.12 & 99.90 & 100.00 & 99.52 & 99.87 \\
\hline \multicolumn{5}{|l|}{ Nigeria } \\
\hline 1981.01-1986.12 & 67.61 & 85.92 & 7.04 & 21.13 \\
\hline \multicolumn{5}{|l|}{ Uganda } \\
\hline 1981.01-1993.10 & 62.75 & 92.81 & 35.95 & 67.32 \\
\hline Average & 73.79 & 93.52 & 39.73 & 62.66 \\
\hline Median & 68.62 & 94.14 & 30.72 & 54.90 \\
\hline Std Deviation & 13.33 & 4.39 & 31.22 & 27.41 \\
\hline
\end{tabular}

Table 5 Managed floating and floating

\begin{tabular}{|c|c|c|c|c|}
\hline \multirow[t]{2}{*}{ Country and Periods of Floating } & \multicolumn{2}{|c|}{$\begin{array}{l}\text { Probability that the monthly } \\
\text { percent change in the nominal } \\
\text { exchange rate falls within: }\end{array}$} & \multicolumn{2}{|c|}{$\begin{array}{l}\text { Probability that the monthly } \\
\text { percent change in foreign } \\
\text { exchange reserves falls within: }\end{array}$} \\
\hline & $\pm 1 \%$ band & $\pm 2.5 \%$ band & $\pm 1 \%$ band & $\pm 2.5 \%$ band \\
\hline \multicolumn{5}{|l|}{ Algeria } \\
\hline 1994.11-2017.12 & 88.49 & 98.92 & 51.44 & 87.77 \\
\hline \multicolumn{5}{|l|}{ Kenya } \\
\hline 1993.10-2017.12 & 59.45 & 89.50 & 48.45 & 83.16 \\
\hline \multicolumn{5}{|l|}{ Nigeria } \\
\hline 1987.01-1993.12 & 79.52 & 96.39 & 32.53 & 65.06 \\
\hline 1999.01-2017.12 & 81.88 & 97.81 & 53.95 & 94.74 \\
\hline \multicolumn{5}{|l|}{ South Africa } \\
\hline 1974.06-2017.12 & 61.80 & 92.71 & 55.28 & 75.43 \\
\hline \multicolumn{5}{|l|}{ Uganda } \\
\hline 1993.11-2017.12 & 56.06 & 87.89 & 53.98 & 82.70 \\
\hline Average & 71.20 & 93.87 & 49.27 & 81.48 \\
\hline Median & 70.66 & 94.55 & 52.70 & 82.93 \\
\hline Std dev & 13.70 & 4.55 & 8.55 & 10.26 \\
\hline
\end{tabular}


Table 6 Interest rate change by regimes: Pegged to USD

\begin{tabular}{|c|c|c|c|c|}
\hline \multirow[t]{2}{*}{ Country and Periods Pegged to USD } & \multicolumn{2}{|c|}{$\begin{array}{l}\text { Probability that the monthly } \\
\text { percent change in the nominal } \\
\text { interest rate falls within: }\end{array}$} & \multicolumn{2}{|c|}{$\begin{array}{l}\text { Probability that the monthly } \\
\text { percent change in the nominal } \\
\text { interest rate falls outside: }\end{array}$} \\
\hline & $\pm 0.25 \%$ band & $\pm 0.5 \%$ band & $\pm 4 \%$ band & $\pm 5 \%$ band \\
\hline \multicolumn{5}{|l|}{ Algeria } \\
\hline $1970.01-1980.12$ & 96.95 & 97.71 & 0.00 & 0.00 \\
\hline \multicolumn{5}{|l|}{ Botswana } \\
\hline $1970.01-1980.12$ & 93.13 & 94.66 & 0.00 & 0.00 \\
\hline \multicolumn{5}{|l|}{ Ghana } \\
\hline $1970.01-1980.12$ & 92.37 & 93.13 & 4.41 & 2.29 \\
\hline 1981.01-1986.08 & 82.35 & 82.35 & 8.82 & 4.41 \\
\hline \multicolumn{5}{|l|}{ Kenya } \\
\hline 1970.01-1980.12 & 56.49 & 71.76 & 0.00 & 0.00 \\
\hline \multicolumn{5}{|l|}{ Morocco } \\
\hline $1970.01-1980.12$ & 99.98 & 99.98 & 0.00 & 0.00 \\
\hline \multicolumn{5}{|l|}{ Nigeria } \\
\hline $1970.01-1980.12$ & 93.13 & 93.89 & 0.76 & 0.76 \\
\hline 1994.01-1998.12 & 86.44 & 91.52 & 0.00 & 0.00 \\
\hline \multicolumn{5}{|l|}{ South Africa } \\
\hline 1970.01-1974.05 & 45.10 & 60.78 & 0.00 & 0.00 \\
\hline \multicolumn{5}{|l|}{ Uganda } \\
\hline $1970.01-1980.12$ & 90.84 & 90.84 & 4.58 & 3.05 \\
\hline Average & 83.68 & 87.66 & 1.86 & 1.05 \\
\hline Median & 91.61 & 92.33 & 0.00 & 0.00 \\
\hline Std dev & 18.21 & 12.47 & 3.06 & 1.62 \\
\hline
\end{tabular}

Tables 6,7 , and 8 shows that interest rate variability was low under floating or managed floating regimes - with only Uganda and Kenya showing any signs of large interest rate changes. Interest rate volatility was highest under basket pegs, largely due to Kenya and Nigeria whose pegs probably lacked credibility and who both moved to declared floating rate regimes.

For fear of floating to be credible hypothesis we would expect exchange rate variability to be relatively low although a floating regime is announced. This low exchange rate variability may stem from policy actions, in which case the reserve volatility or interest rate volatility is likely to be high compared to true floaters. In pure float and pure pegged regimes the correlation between the change in reserves and the change in the exchange rate should be insignificantly different from zero. On the other hand, a negative sign denotes some intervention in the market and may indicate a "fear of floating" if the exchange rate is depreciation (rising) whilst reserves are falling. Similarly a positive correlation between exchange rate changes and interest rate changes may suggest that central banks are "leaning-into-the-wind" to slow the rate of depreciation or appreciation in a floating rate regime. 
Table 7 Pegged to basket

\begin{tabular}{|c|c|c|c|c|}
\hline \multirow[t]{2}{*}{$\begin{array}{l}\text { Country and Periods } \\
\text { Basket pegs }\end{array}$} & \multicolumn{2}{|c|}{$\begin{array}{l}\text { Probability that the monthly } \\
\text { percent change in the nominal } \\
\text { interest rate falls within: }\end{array}$} & \multicolumn{2}{|c|}{$\begin{array}{l}\text { Probability that the monthly } \\
\text { percent change in the nominal } \\
\text { interest rate falls outside: }\end{array}$} \\
\hline & \pm 0.25 band & $\pm 0.5 \%$ band & $\pm 4 \%$ band & $\pm 5 \%$ band \\
\hline \multicolumn{5}{|l|}{ Algeria } \\
\hline 1981.01-1994.10 & 99.40 & 99.40 & 0.00 & 0.00 \\
\hline \multicolumn{5}{|l|}{ Botswana } \\
\hline 1981.01-2017.12 & 91.44 & 97.44 & 0.00 & 0.00 \\
\hline \multicolumn{5}{|l|}{ Ghana } \\
\hline 1986.09-2017.12 & 80.59 & 87.23 & 1.86 & 0.00 \\
\hline \multicolumn{5}{|l|}{ Kenya } \\
\hline 1981.01-1993.09 & 16.34 & 35.95 & 10.46 & 9.15 \\
\hline \multicolumn{5}{|l|}{ Morocco } \\
\hline 1981.01-2017.12 & 99.95 & 99.99 & 0.00 & 0.00 \\
\hline \multicolumn{5}{|l|}{ Nigeria } \\
\hline 1981.01-1986.12 & 93.06 & 93.06 & 2.78 & 1.52 \\
\hline \multicolumn{5}{|l|}{ Uganda } \\
\hline 1981.01-1993.10 & 38.56 & 46.41 & 7.19 & 4.58 \\
\hline $\begin{array}{l}\text { Average } \\
\text { Median }\end{array}$ & 91.44 & 93.06 & 1.86 & 0.00 \\
\hline Std Deviation & 33.19 & 26.99 & 4.11 & 3.51 \\
\hline
\end{tabular}

Table 8 Managed floating and floating

\begin{tabular}{|c|c|c|c|c|}
\hline \multirow[t]{2}{*}{ Country and Periods of Floating } & \multicolumn{2}{|c|}{$\begin{array}{l}\text { Probability that the monthly } \\
\text { percent change in the nominal } \\
\text { interest rate falls within: }\end{array}$} & \multicolumn{2}{|c|}{$\begin{array}{l}\text { Probability that the monthly } \\
\text { percent change in the nominal } \\
\text { interest rate falls outside: }\end{array}$} \\
\hline & \pm 0.25 band & $\pm 0.5 \%$ band & $\pm 4 \%$ band & $\pm 5 \%$ band \\
\hline \multicolumn{5}{|l|}{ Algeria } \\
\hline 1994.11-2017.12 & 98.92 & 98.92 & 0.00 & 0.00 \\
\hline \multicolumn{5}{|l|}{ Kenya } \\
\hline 1993.10-2017.12 & 50.86 & 65.29 & 1.03 & 0.00 \\
\hline \multicolumn{5}{|l|}{ Nigeria } \\
\hline 1987.01-1993.12 & 80.72 & 80.72 & 0.00 & 0.00 \\
\hline 1999.01-2017.12 & 94.74 & 96.49 & 0.00 & 0.00 \\
\hline \multicolumn{5}{|l|}{ South Africa } \\
\hline $1974.06-2017.12$ & 84.13 & 88.72 & 0.00 & 0.00 \\
\hline \multicolumn{5}{|l|}{ Uganda } \\
\hline 1993.11-2017.12 & 75.43 & 84.08 & 0.69 & 0.35 \\
\hline Average & 80.80 & 85.70 & 0.29 & 0.06 \\
\hline Median & 82.43 & 86.40 & 0.00 & 0.00 \\
\hline Std dev & 17.08 & 12.20 & 0.46 & 0.14 \\
\hline
\end{tabular}


The final two columns of Table 2 shows the correlation coefficients between exchange rate changes, and reserve and interest rate changes for all countries in the sample and across the various exchange rate regimes. "Leaning-into-the-wind" is significant in Ghana, Kenya, Morocco, Nigeria and Uganda over specific sub periods and market negatively signed and significant for Morocco, Nigeria, South Africa and Uganda and over certain sub-periods. There are six instances of booth features occurring together (Algeria, January 1980 to October 1994; Kenya, October 1993 to December 2017; Morocco, January 1970 to December 1980; Nigeria, January 1970 to December 1980 and January 1987 to December 1993; South Africa, June 1974 to December 2017; and Uganda, January 1981 to October 1993), although only in the case of Nigeria from January 1987 to December 1993 are both correlation statistically significant at the $5 \%$ level, but in four of the six instances one of the coefficients are statistically significant.

Botswana and Kenya (January 1981 to September 1993) have positive and significant correlations between exchange rate changes and reserve changes, despite declaring a pegged regime, suggesting that reserves were rising to prevent the exchange rate from appreciating too rapidly.

\section{Econometric Threshold Analysis and Results}

The descriptive analysis suggests that there may be a "fear of floating" for some of our sample countries over specific periods of time. Specifically: Algeria (January 1980 to October 1994); Kenya (October 1993 to December 2017); Morocco (January 1970 to December 1980); Nigeria (January 1970 to December 1980 and January 1987 to December 1993); South Africa (June 1974 to December 2017); and Uganda, (January 1981 to October 1993). As identifying a relationship between exchange rate changes and reserves changes is problematic due to the simultaneity problem and therefore we choose to use a VAR model, which treats all variables as endogenous to addresses this issue. Therefore in this section we attempt to test the fear of floating hypothesis using a bi-variate threshold VAR model, following Tsay (1998) and Balke and Fomby (1997). ${ }^{6}$ The advantage of this non-linear approach is that not only can the threshold level for reserves, $\gamma$, vary between countries, but so can the delay parameter, $d$, which indicates how long it takes the effect of crossing the estimated reserves threshold to be felt by the rest of the system.

Defining the vector $X$ as $X=[\Delta e, \Delta r]$, the bivariate VAR can be written as

$$
\left[\begin{array}{c}
\Delta e_{t} \\
\Delta r_{t}
\end{array}\right]=\left[\begin{array}{ll}
\beta_{11 i}(s) & \beta_{12 i}(s) \\
\beta_{21 i}(s) & \beta_{22 i}(s)
\end{array}\right]\left[\begin{array}{c}
\Delta e_{t-i} \\
\Delta r_{t-i}
\end{array}\right]+\left[\begin{array}{l}
u_{e t} \\
u_{r t}
\end{array}\right]
$$

where $u_{e t}$ and $u_{r t}$ are random error terms, the $\beta(s)$ 's are the system parameters to be estimated with $i$ period lags, where $s$ defines the estimated threshold of the two reserve

\footnotetext{
${ }^{6}$ We attempted estimating a four-variable model that included reserves, exchange rates, money supply and interest rate, to capture the effect of monetary policy. However, both money supply and interest rate turned out to be insignificant. This may not be unconnected to the underdeveloped financial systems in the sample countries, except perhaps South Africa.
} 
regimes such that $s_{t}=\{h, l\}$ where $h$ and $l$ refer to the high- and low-reserve regimes, respectively. The regimes depend on the country's reserves, such that:

$$
\left\{\begin{array}{lll}
S_{t}=h & \text { if } & r_{t-d}>\bar{\gamma} \\
S_{t}=l & \text { if } & r_{t-d} \leq \bar{\gamma}
\end{array}\right.
$$

where $r_{t}$ denotes the reserves, $\bar{\gamma}$ denotes the threshold between high and low reserves regimes and $d$ denotes the delay parameter.

We follow the conventional procedure in estimating the TVAR model ${ }^{7}$ in (2). We first determine the number of lags $(p)$ on the endogenous variables using the Information Criteria and test for the existence of multiple regimes using the $C(d)$ threshold test statistic. ${ }^{8}$ The testing procedure re-orders the data according to ascending values of the threshold variable and estimates (2) using sub-samples of the data which partition the VAR into high and low regimes based on the reserve threshold.

Tables 9 and 10 reports the estimated multivariate threshold, $\mathrm{C}(\mathrm{d})$, along with the delay parameters, $\mathrm{d}$, and the threshold values, $\gamma$. The delay parameters are reported for up to 24 months for each of the countries whose $p$-values indicate that they are all significant. The estimated threshold values range from 12.50 for Botswana to 7.16 for Uganda. The results indicate that the threshold for countries with de jure pegged regimes, Botswana and Morocco are the largest at 12.50 and 10.57, respectively. Since the threshold variable is the reserves this suggests that countries with pegged exchange rate regimes seem to tolerate higher reserve volatility than those with more flexible regimes. This is as expected and not evidence of fear of floating, although what is important to note is that countries with more flexible exchange rate regimes also have a relatively high reserve thresholds, in excess of 7.00 ; for example, South Africa at 7.75 and Nigeria at 8.45, which are indicative of substantial intervention in the foreign exchange market.

The impulse response functions (irf). are computed from these estimated regimedependent VARs where generalized impulse responses (Pesaran and Shin 1998) that do not require orthogonalization of shocks and are also invariant to the ordering of the variables in the VAR. ${ }^{9}$ Impulse response functions allow the possibility of investigating the dynamic response of the variables to different shocks within the system. The impulse response functions (irfs) derived from the estimated threshold VAR model show the responses of exchange rate changes and reserve changes to one another in both high (h) and low (l) reserve regimes over time and are shown in Fig. 1. These irfs are regime-dependent and therefore we report the responses of the variables to the shocks in both high $(h)$ and low $(l)$ regimes. The variance decompositions in Tables 11 ,

\footnotetext{
${ }^{7}$ See for example Çatik and Martin (2012) and Ahmad et al. (2014).

${ }^{8}$ The C(d) Test Statistics, asymptotically follow a Chi-square distribution and test for the existence of a threshold VAR against a linear VAR and also calculates the threshold value, $\gamma$, and the delay parameter, $d$. The $\mathrm{C}(\mathrm{d})$ test is used to re-arrange the variables in the VAR in ascending values of the threshold variable and the model is then estimated recursively. Tsay (1998) shows that a choosing an appropriate starting value for $\mathrm{m}_{0}$ is very important, so as not to introduce bias in the empirical distributions of $\mathrm{C}(\mathrm{d})$, so we have used different values of $\mathrm{m}_{0}$ in order to determine the optimum starting value.

${ }^{9}$ We have also computed the orthogonalized impulse response functions for robustness check and the results are largely consistent.
} 
Table 9 Multivariate threshold test

\begin{tabular}{|c|c|c|c|c|c|c|}
\hline \multirow[t]{2}{*}{ Country } & \multirow[t]{2}{*}{ Delay Parameter, $d$} & \multicolumn{3}{|l|}{$C(d)$} & \multirow[t]{2}{*}{ p-values } & \multirow[t]{2}{*}{ Threshold Value, $\gamma$} \\
\hline & & $\mathrm{m}_{0}=150$ & $\mathrm{~m}_{0}=180$ & $\mathrm{~m}_{0}=250$ & & \\
\hline \multirow[t]{8}{*}{ Algeria } & $d=1$ & 418.62 & 460.68 & 439.12 & 0.00 & \multirow[t]{8}{*}{9.73} \\
\hline & $d=2$ & 421.21 & 437.21 & 422.10 & 0.00 & \\
\hline & $d=3$ & 422.10 & 465.66 & 456.77 & 0.00 & \\
\hline & $d=4$ & 435.40 & 456.97 & 448.03 & 0.00 & \\
\hline & $d=8$ & 439.47 & 435.32 & 443.34 & 0.00 & \\
\hline & $d=12$ & 600.81 & 532.75 & 457.18 & 0.00 & \\
\hline & $d=18$ & 546.95 & 599.17 & 519.07 & 0.00 & \\
\hline & $d=24$ & 669.45 & 730.15 & 589.76 & 0.00 & \\
\hline \multirow[t]{8}{*}{ Botswana } & $d=1$ & 457.41 & 541.42 & 509.72 & 0.00 & \multirow[t]{8}{*}{12.50} \\
\hline & $d=2$ & 452.38 & 520.12 & 483.57 & 0.00 & \\
\hline & $d=3$ & 448.22 & 529.15 & 544.82 & 0.00 & \\
\hline & $d=4$ & 456.94 & 515.67 & 439.84 & 0.00 & \\
\hline & $d=8$ & 353.71 & 434.53 & 407.71 & 0.00 & \\
\hline & $d=12$ & 372.23 & 468.60 & 409.34 & 0.00 & \\
\hline & $d=18$ & 383.80 & 538.54 & 389.33 & 0.00 & \\
\hline & $d=24$ & 448.52 & 508.54 & 359.49 & 0.00 & \\
\hline \multirow[t]{8}{*}{ Ghana } & $d=1$ & 556.26 & 654.06 & 608.92 & 0.00 & \multirow[t]{8}{*}{7.35} \\
\hline & $d=2$ & 587.16 & 649.16 & 554.02 & 0.00 & \\
\hline & $d=3$ & 588.93 & 618.83 & 630.41 & 0.00 & \\
\hline & $d=4$ & 653.50 & 664.31 & 591.40 & 0.00 & \\
\hline & $d=8$ & 718.72 & 733.52 & 578.31 & 0.00 & \\
\hline & $d=12$ & 708.38 & 684.07 & 531.07 & 0.00 & \\
\hline & $d=18$ & 551.57 & 811.86 & 594.86 & 0.00 & \\
\hline & $d=24$ & 653.20 & 725.42 & 298.12 & 0.00 & \\
\hline \multirow[t]{8}{*}{ Kenya } & $d=1$ & 546.17 & 357.21 & 466.86 & 0.00 & \multirow[t]{8}{*}{7.96} \\
\hline & $d=2$ & 511.62 & 391.12 & 461.24 & 0.00 & \\
\hline & $d=3$ & 504.28 & 399.09 & 473.02 & 0.00 & \\
\hline & $d=4$ & 502.65 & 413.38 & 451.74 & 0.00 & \\
\hline & $d=8$ & 460.57 & 448.53 & 376.88 & 0.00 & \\
\hline & $d=12$ & 420.37 & 424.90 & 414.86 & 0.00 & \\
\hline & $d=18$ & 350.23 & 440.87 & 338.70 & 0.00 & \\
\hline & $d=24$ & 341.65 & 418.18 & 331.57 & 0.00 & \\
\hline
\end{tabular}

12 , and 13 show the effect of a unit shocks to $u_{e}$ and $u_{r}$ on the variance to exchange rate and reserve equations.

Table 2 shows both de jure and de facto exchange rate regimes of the countries covered. The de facto regimes were obtained by using models of Frankel et al. (2001) and Harvey et al. (2006) as in Ahmad et al. (2011). The table indicates that Algeria, Ghana, Kenya, Nigeria, South Africa have declared that their regimes for most of the 
Table 10 Multivariate Threshold Test

\begin{tabular}{|c|c|c|c|c|c|c|}
\hline \multirow[t]{2}{*}{ Country } & \multirow[t]{2}{*}{ Delay Parameter, $d$} & \multicolumn{3}{|l|}{$C(d)$} & \multirow[t]{2}{*}{ p-Values } & \multirow[t]{2}{*}{ Threshold Value, $\gamma$} \\
\hline & & $\mathrm{m}_{0}=150$ & $\mathrm{~m}_{0}=180$ & $\mathrm{~m}_{0}=250$ & & \\
\hline \multirow[t]{8}{*}{ Morocco } & $d=1$ & 304.01 & 441.86 & 338.74 & 0.00 & \multirow[t]{8}{*}{10.57} \\
\hline & $d=2$ & 336.22 & 456.93 & 356.88 & 0.00 & \\
\hline & $d=3$ & 206.81 & 484.61 & 337.82 & 0.00 & \\
\hline & $d=4$ & 321.52 & 481.35 & 341.98 & 0.00 & \\
\hline & $d=8$ & 109.33 & 499.92 & 328.63 & 0.00 & \\
\hline & $d=12$ & 323.03 & 508.33 & 324.22 & 0.00 & \\
\hline & $d=18$ & 323.87 & 446.23 & 300.13 & 0.00 & \\
\hline & $d=24$ & 344.66 & 506.01 & 389.98 & 0.00 & \\
\hline \multirow[t]{8}{*}{ Nigeria } & $d=1$ & 457.41 & 541.42 & 509.72 & 0.00 & \multirow[t]{8}{*}{8.45} \\
\hline & $d=2$ & 452.38 & 520.12 & 483.57 & 0.00 & \\
\hline & $d=3$ & 448.22 & 529.15 & 454.82 & 0.00 & \\
\hline & $d=4$ & 456.94 & 515.67 & 439.84 & 0.00 & \\
\hline & $d=8$ & 353.71 & 434.53 & 407.71 & 0.00 & \\
\hline & $d=12$ & 372.23 & 468.60 & 409.34 & 0.00 & \\
\hline & $d=18$ & 383.80 & 538.54 & 389.33 & 0.00 & \\
\hline & $d=24$ & 448.52 & 508.54 & 359.49 & 0.00 & \\
\hline \multirow[t]{8}{*}{ South Africa } & $d=1$ & 444.68 & 328.05 & 373.18 & 0.00 & \multirow[t]{8}{*}{7.75} \\
\hline & $d=2$ & 479.47 & 319.20 & 382.25 & 0.00 & \\
\hline & $d=3$ & 494.07 & 311.09 & 467.30 & 0.00 & \\
\hline & $d=4$ & 489.83 & 323.27 & 396.63 & 0.00 & \\
\hline & $d=8$ & 382.20 & 305.68 & 366.79 & 0.00 & \\
\hline & $d=12$ & 406.80 & 341.20 & 429.89 & 0.00 & \\
\hline & $d=18$ & 348.64 & 259.61 & 415.72 & 0.00 & \\
\hline & $d=24$ & 311.36 & 253.83 & 340.07 & 0.00 & \\
\hline \multirow[t]{8}{*}{ Uganda } & $d=1$ & 510.81 & 422.46 & 338.75 & 0.00 & \multirow[t]{8}{*}{7.16} \\
\hline & $d=2$ & 492.75 & 435.63 & 363.29 & 0.00 & \\
\hline & $d=3$ & 467.65 & 428.41 & 361.31 & 0.00 & \\
\hline & $d=4$ & 456.74 & 395.04 & 342.84 & 0.00 & \\
\hline & $d=8$ & 588.42 & 396.97 & 393.89 & 0.00 & \\
\hline & $d=12$ & 227.30 & 351.52 & 386.23 & 0.00 & \\
\hline & $d=18$ & 424.65 & 250.95 & 332.04 & 0.00 & \\
\hline & $d=24$ & 463.86 & 285.10 & 362.66 & 0.00 & \\
\hline
\end{tabular}

sample period is floating. Botswana and Morocco are two countries which have had a pegged regime as their de jure regime for the whole period.

The results for Algeria indicate that the exchange rates have responded insignificantly to positive changes in reserves in the high reserve regime, but appreciated in the low regime. The reserves, on the other hand, responded positively in the high reserve regime, but negatively in the low regime. The results for Uganda also show that, although the exchange rates have reacted insignificantly to positive reserve shocks, the 


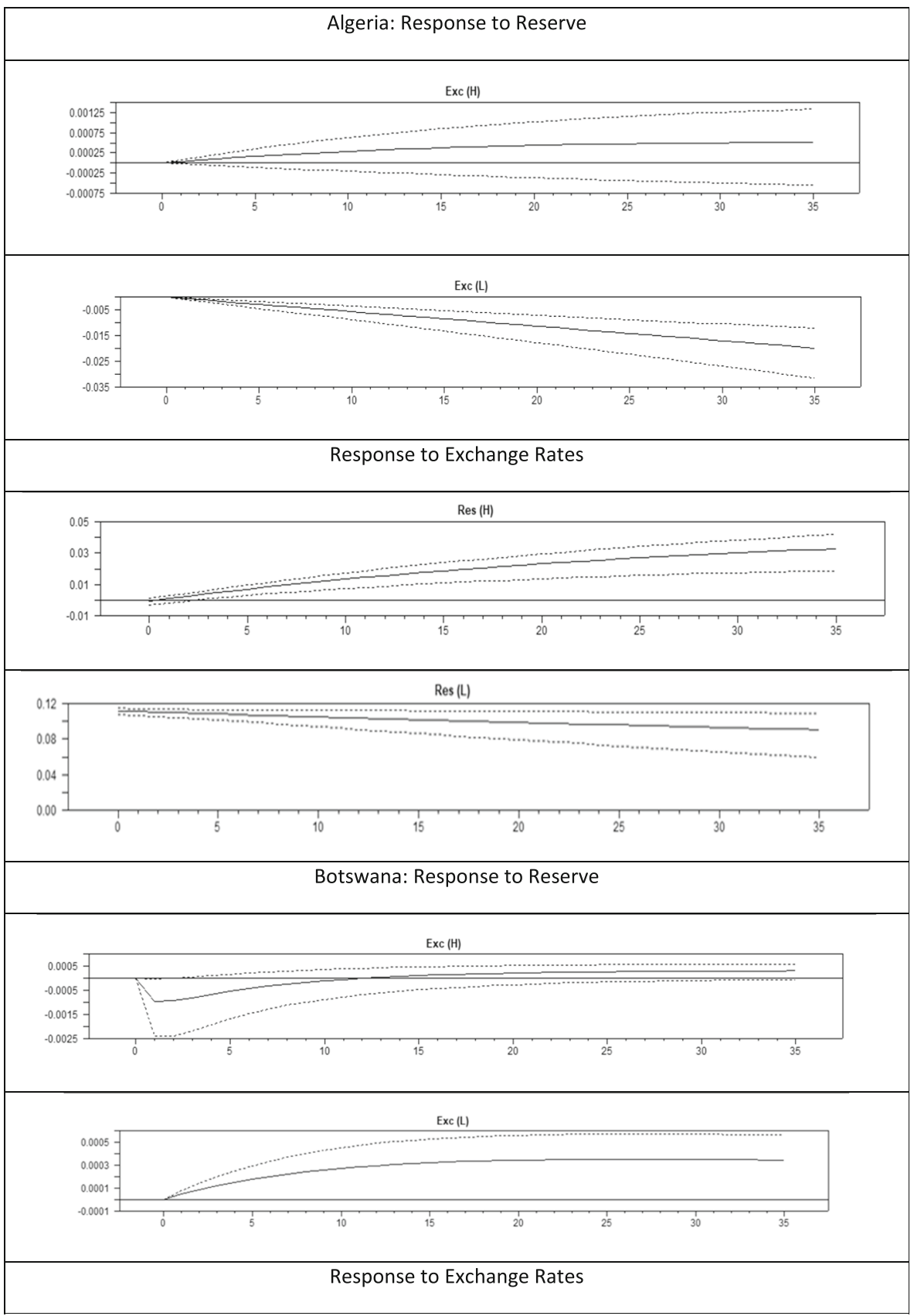

Fig. 1 The impulse response functions

reserves responded negatively to exchange rate depreciation in both low and high regimes. For both countries this suggests the existence of fear of floating in the low regime as the country's de jure exchange rate was a floating one for the period as indicated in Table 2. 

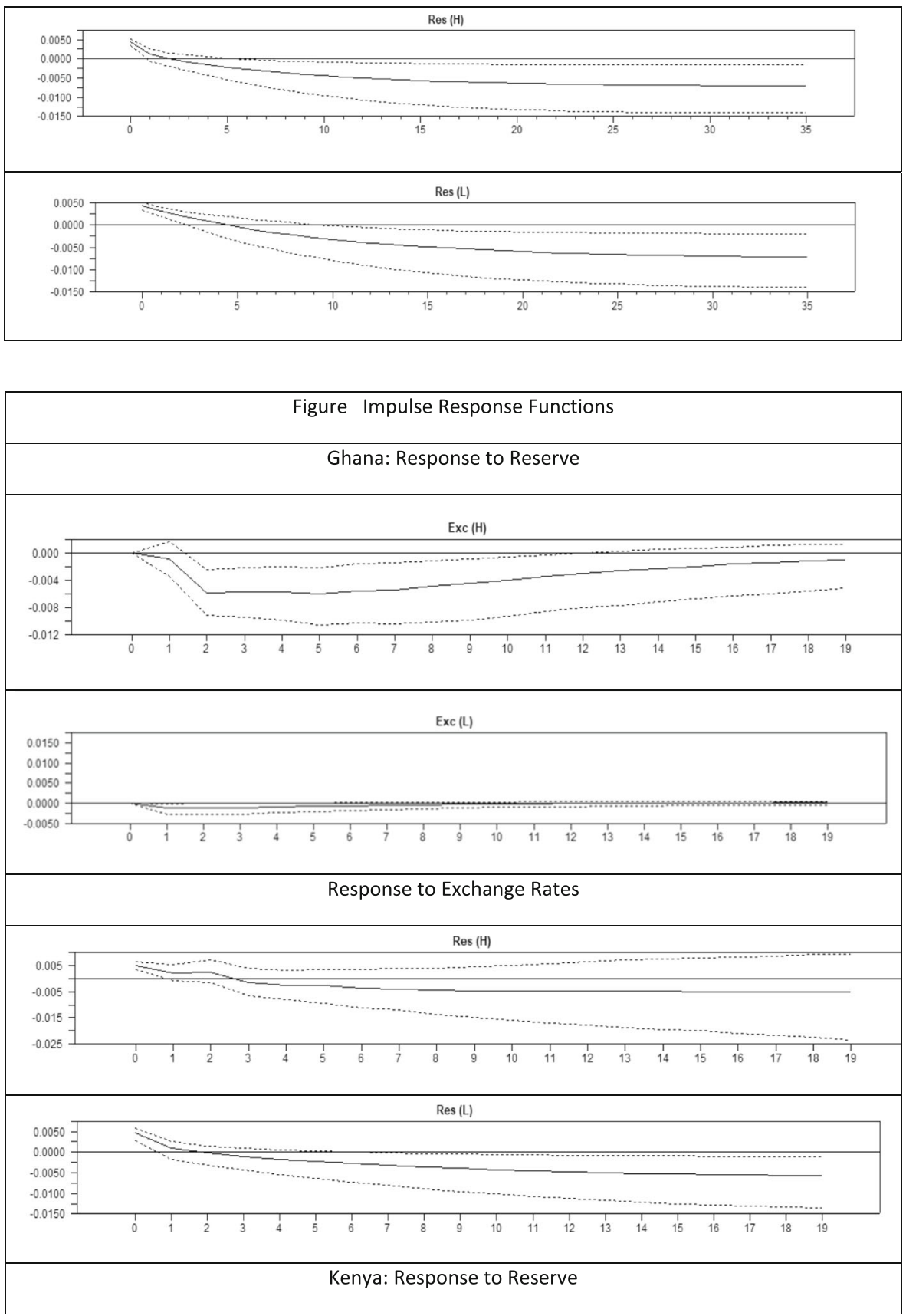

Fig. 1 (continued)

The results for Kenya indicate the presence of fear of floating as its exchange rates responded to positive reserves shocks by appreciating in both low and high regimes. In the same vein, reserves responded by decreasing in response to exchange rate 

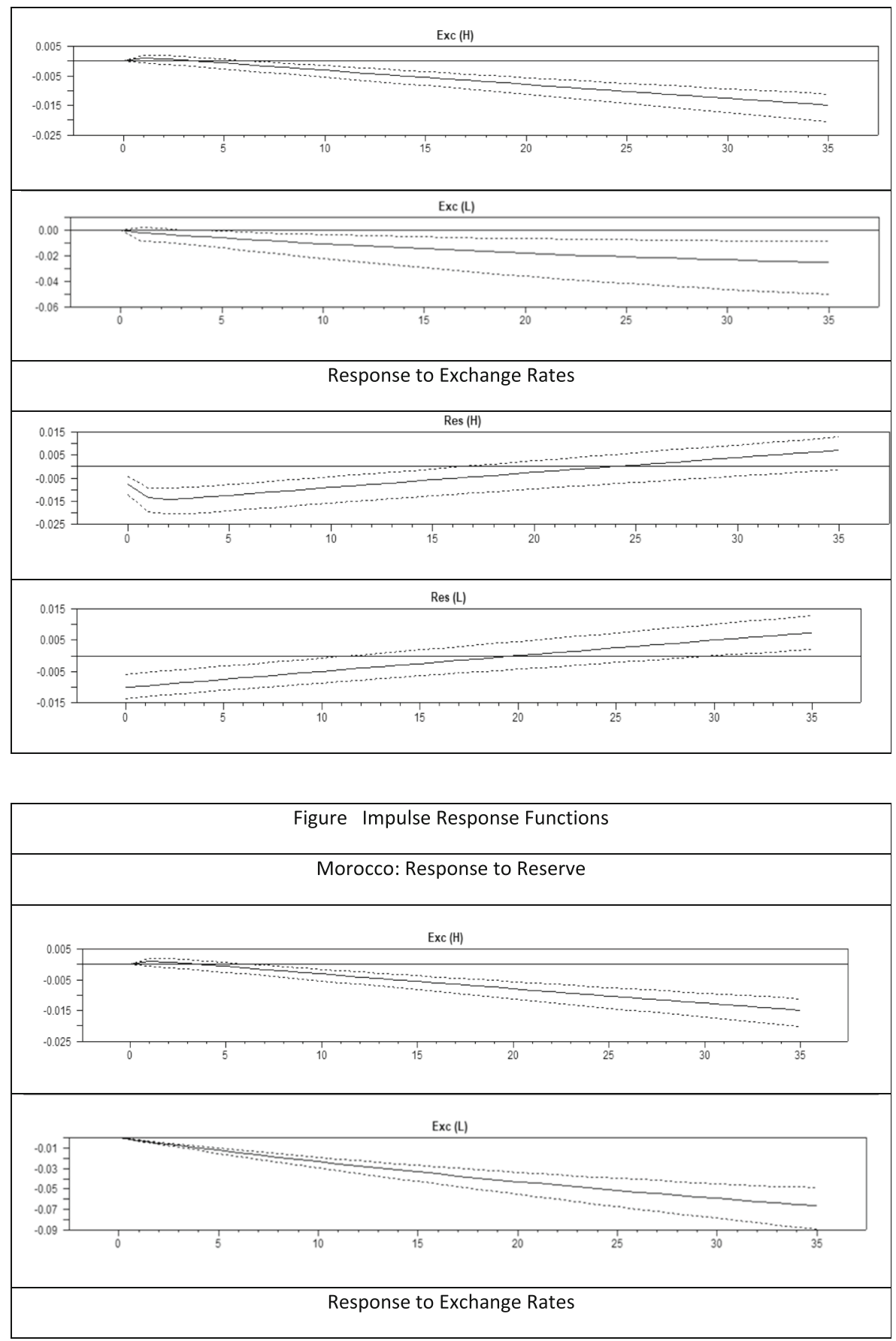

Fig. 1 (continued)

depreciation. Similarly the results for Nigeria indicate that exchange rates have responded to positive reserve shocks in the low regime by marginally appreciating 


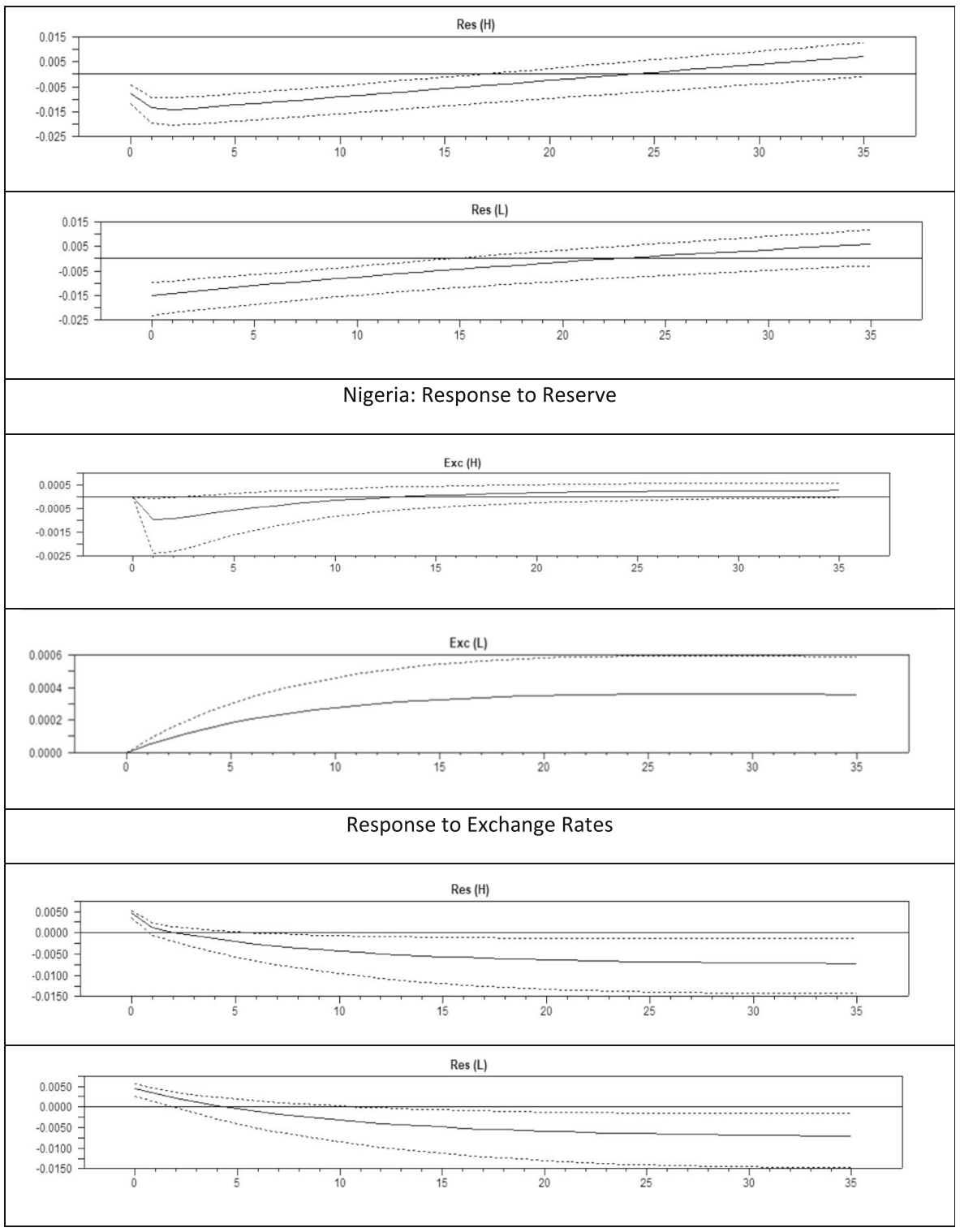

Fig. 1 (continued)

while its reserves to exchange rate depreciation by decreasing in both low and high regimes. Reduction of reserves in response to exchange rate appreciation in this context, is an indication of fear of floating as the country's de jure regime is a floating.

Results for Ghana are generally insignificant responses, except the exchange rates in the high regime that responded to positive reserve shocks by appreciating for about five months after a lag of a couple of months. This suggests that the country suffers from fear of floating only in that regime. South Africa's results show that neither exchange rate nor reserves responded to positive shock in reserves and exchange rates, 


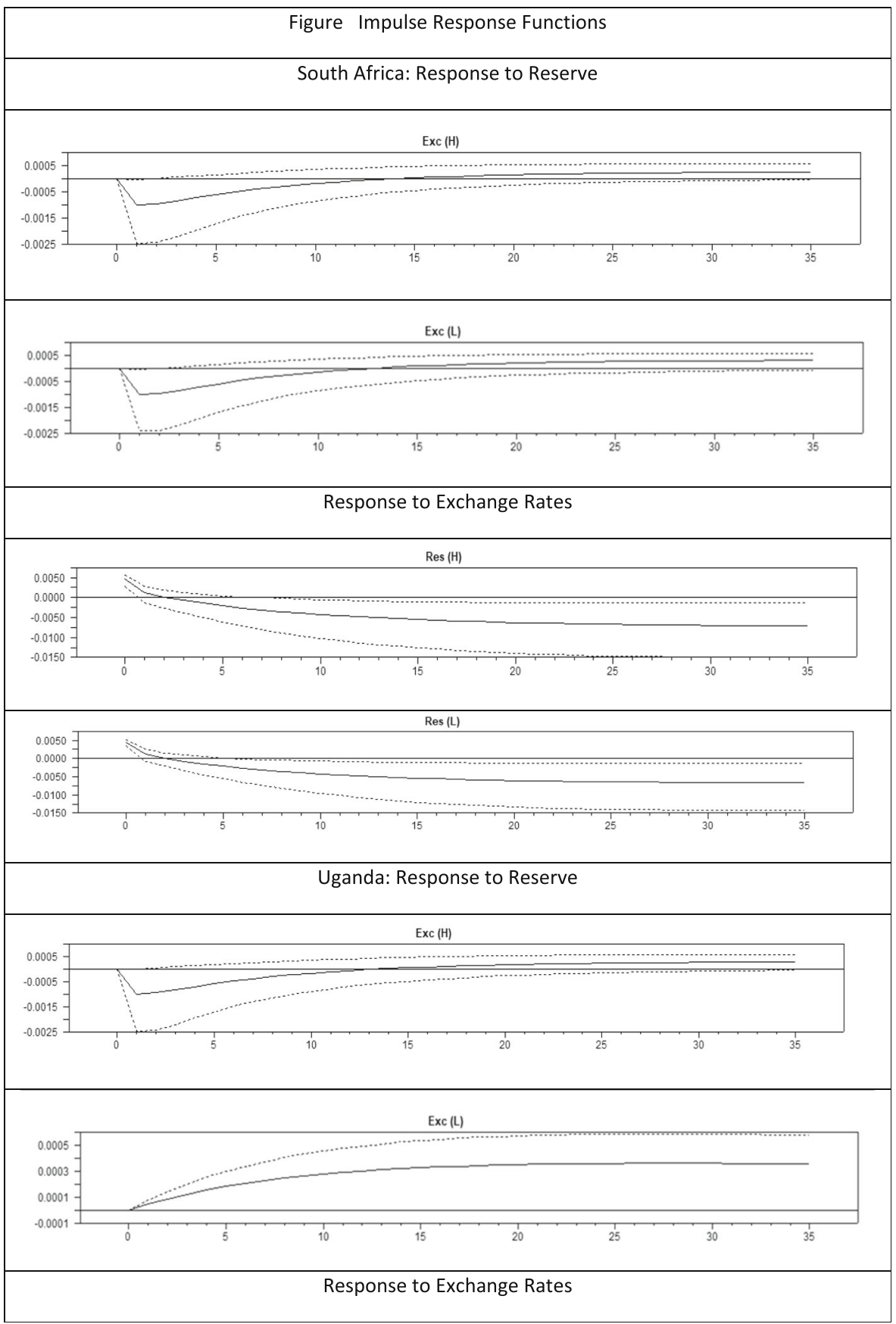

Fig. 1 (continued)

respectively, for both the low and high reserve regimes. This is consistent with the declared de jure flexible exchange rate regime of the country for the sample period. However, the reserves seem to respond to exchange rates depreciation by a slight 


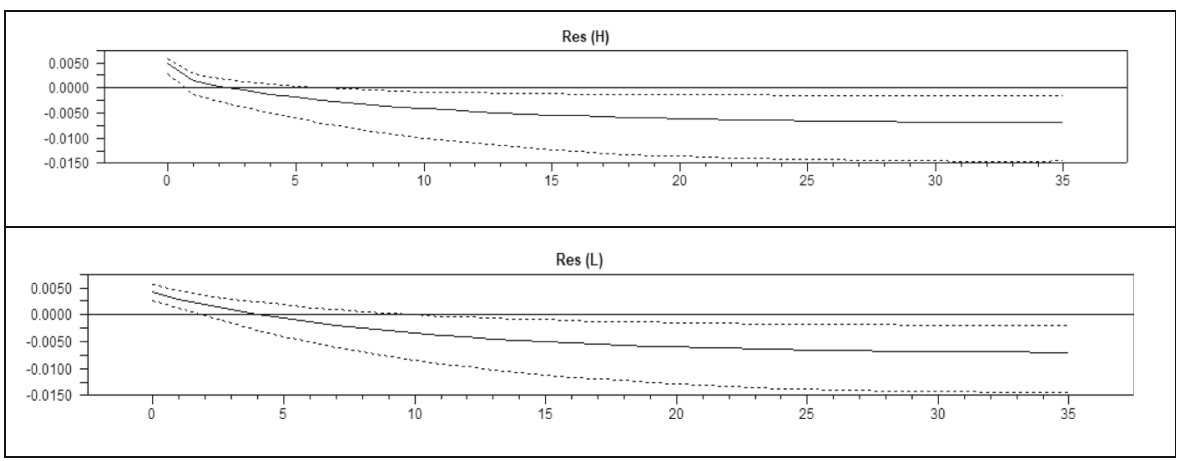

Fig. 1 (continued)

Table 11 Variance Decomposition

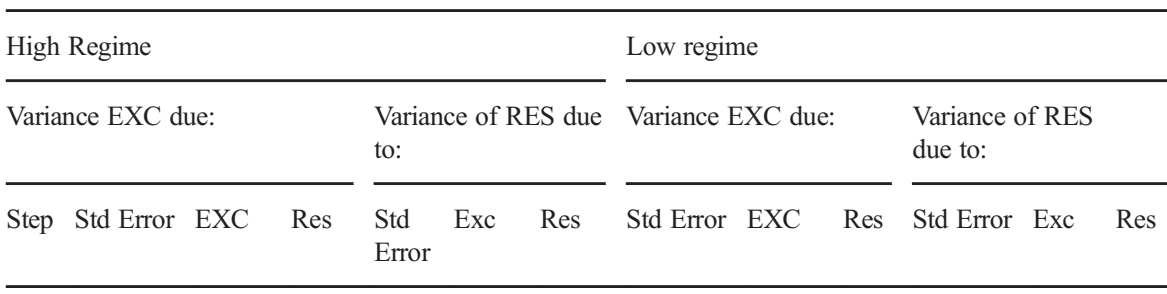

Variance Decomposition: Algeria

\begin{tabular}{lllllllllllll}
1 & 0.02 & 100.00 & 0.00 & 0.03 & 0.02 & 99.98 & 0.03 & 100.00 & 0.00 & 0.11 & 0.61 & 99.39 \\
2 & 0.02 & 100.00 & 0.00 & 0.05 & 0.07 & 99.93 & 0.04 & 99.99 & 0.01 & 0.16 & 0.59 & 99.41 \\
3 & 0.03 & 100.00 & 0.00 & 0.06 & 0.26 & 99.74 & 0.05 & 99.95 & 0.05 & 0.19 & 0.57 & 99.43 \\
4 & 0.03 & 100.00 & 0.00 & 0.07 & 0.60 & 99.40 & 0.06 & 99.90 & 0.10 & 0.22 & 0.55 & 99.45 \\
12 & 0.05 & 99.98 & 0.02 & 0.11 & 7.23 & 92.77 & 0.11 & 99.00 & 1.00 & 0.35 & 0.41 & 99.59 \\
16 & 0.05 & 99.96 & 0.04 & 0.13 & 12.11 & 87.89 & 0.14 & 98.29 & 1.71 & 0.39 & 0.36 & 99.64 \\
24 & 0.06 & 99.91 & 0.09 & 0.17 & 22.49 & 77.51 & 0.17 & 96.58 & 3.42 & 0.44 & 0.28 & 99.72 \\
Variance Decomposition: Botswana & & & & & & & & \\
2 & 0.01 & 100.00 & 0.00 & 0.02 & 5.80 & 94.20 & 0.02 & 100.00 & 0.00 & 0.02 & 5.82 & 94.18 \\
3 & 0.01 & 73.09 & 26.91 & 0.03 & 3.03 & 96.97 & 0.02 & 99.76 & 0.24 & 0.03 & 2.89 & 97.11 \\
4 & 0.01 & 56.86 & 43.14 & 0.03 & 2.00 & 98.00 & 0.03 & 99.66 & 0.34 & 0.03 & 1.90 & 98.10 \\
12 & 0.01 & 46.46 & 53.54 & 0.04 & 1.53 & 98.47 & 0.03 & 99.62 & 0.38 & 0.04 & 1.50 & 98.50 \\
16 & 0.01 & 31.38 & 68.62 & 0.07 & 3.69 & 96.31 & 0.04 & 99.63 & 0.37 & 0.07 & 2.60 & 97.40 \\
24 & 0.01 & 30.91 & 69.09 & 0.09 & 5.68 & 94.32 & 0.04 & 99.64 & 0.36 & 0.08 & 3.63 & 96.37 \\
Variance Decomposition: & Ghana & & & & & & & & & \\
1 & 0.04 & 100.00 & 0.00 & 0.10 & 5.15 & 94.85 & 0.04 & 100.00 & 0.00 & 0.05 & 0.01 & 99.99 \\
2 & 0.06 & 99.75 & 0.25 & 0.13 & 3.87 & 96.13 & 0.06 & 99.75 & 0.25 & 0.06 & 0.29 & 99.71 \\
3 & 0.07 & 99.81 & 0.19 & 0.16 & 2.54 & 97.46 & 0.07 & 99.81 & 0.19 & 0.06 & 0.63 & 99.37 \\
4 & 0.07 & 99.85 & 0.15 & 0.18 & 2.08 & 97.92 & 0.07 & 99.85 & 0.15 & 0.06 & 0.71 & 99.29 \\
12 & 0.11 & 99.28 & 0.72 & 0.28 & 3.76 & 96.24 & 0.11 & 99.28 & 0.72 & 0.09 & 2.84 & 97.16 \\
16 & 0.12 & 98.58 & 1.42 & 0.31 & 4.23 & 95.77 & 0.12 & 98.58 & 1.42 & 0.10 & 5.76 & 94.24 \\
24 & 0.14 & 96.76 & 3.24 & 0.34 & 5.05 & 94.95 & 0.14 & 96.76 & 3.24 & 0.11 & 14.19 & 85.81 \\
\hline
\end{tabular}


decrease, perhaps reflecting difficulties the currency experience during the latter period of the sample.

The reported irfs of Botswana show that the exchange rates responded insignificantly to positive changes in reserves, but the reserves responded negatively to exchange rates depreciation in both the low and high regimes. This seems to be consistent with the de jure regime declared by the country as a pegged one. Similarly, Morocco's results show that the country's exchange rates responded to positive reserves shock by appreciating in both the low and high regimes. Similarly, its reserves decrease in responding to exchange rate depreciation, both of which are consonant with a declared fixed exchange rate regime.

Overall there is evidence that the fear of floating does exist among the floaters in the sample except perhaps for South Africa. This is, of course, consistent with South African being a more developed economy with deeper financial markets. The results for countries that report a peg as their de jure regimes seem to suggest that their de facto regimes are same as the declared ones.

Table 12 Variance Decomposition

\begin{tabular}{|c|c|c|c|c|c|c|c|c|c|c|c|c|}
\hline \multicolumn{7}{|c|}{ High Regime } & \multicolumn{6}{|c|}{ Low Regime } \\
\hline \multicolumn{4}{|c|}{ Variance EXC due: } & \multicolumn{3}{|c|}{ Variance of RES due to: } & \multicolumn{3}{|c|}{ Variance EXC due: } & \multicolumn{3}{|c|}{ Variance of RES due to: } \\
\hline Step & Std Error & $\mathrm{EXC}$ & Res & Std Error & Exc & Res & Std Error & $\mathrm{EXC}$ & Res & Std Error & Exc & Res \\
\hline \multicolumn{13}{|c|}{ Variance Decomposition: Morocco } \\
\hline 2 & 0.13 & 100.00 & 0.00 & 0.19 & 0.25 & 99.75 & 0.13 & 100.00 & 0.00 & 0.19 & 0.25 & 99.75 \\
\hline 3 & 0.18 & 99.99 & 0.01 & 0.26 & 0.14 & 99.86 & 0.18 & 99.99 & 0.01 & 0.26 & 0.14 & 99.86 \\
\hline 4 & 0.22 & 99.98 & 0.02 & 0.32 & 0.10 & 99.90 & 0.22 & 99.98 & 0.02 & 0.32 & 0.10 & 99.90 \\
\hline 12 & 0.26 & 99.97 & 0.03 & 0.36 & 0.08 & 99.92 & 0.26 & 99.97 & 0.03 & 0.36 & 0.08 & 99.92 \\
\hline 16 & 0.43 & 99.72 & 0.28 & 0.56 & 0.09 & 99.91 & 0.43 & 99.72 & 0.28 & 0.56 & 0.09 & 99.91 \\
\hline 24 & 0.49 & 99.54 & 0.46 & 0.62 & 0.13 & 99.87 & 0.49 & 99.54 & 0.46 & 0.62 & 0.13 & 99.87 \\
\hline \multicolumn{13}{|c|}{ Variance Decomposition: Kenya } \\
\hline 1 & 0.05 & 100.00 & 0.00 & 0.19 & 0.17 & 99.83 & 0.05 & 100.00 & 0.00 & 0.19 & 0.17 & 99.83 \\
\hline 2 & 0.07 & 99.97 & 0.03 & 0.26 & 0.31 & 99.69 & 0.07 & 99.97 & 0.03 & 0.26 & 0.31 & 99.69 \\
\hline 3 & 0.08 & 99.91 & 0.09 & 0.31 & 0.37 & 99.63 & 0.08 & 99.91 & 0.09 & 0.31 & 0.37 & 99.63 \\
\hline 4 & 0.10 & 99.82 & 0.18 & 0.36 & 0.39 & 99.61 & 0.10 & 99.82 & 0.18 & 0.36 & 0.39 & 99.61 \\
\hline 12 & 0.17 & 98.23 & 1.77 & 0.54 & 0.38 & 99.62 & 0.17 & 98.23 & 1.77 & 0.54 & 0.38 & 99.62 \\
\hline 16 & 0.19 & 97.08 & 2.92 & 0.58 & 0.36 & 99.64 & 0.19 & 97.08 & 2.92 & 0.58 & 0.36 & 99.64 \\
\hline 24 & 0.24 & 94.52 & 5.48 & 0.64 & 0.31 & 99.69 & 0.24 & 94.52 & 5.48 & 0.64 & 0.31 & 99.69 \\
\hline \multicolumn{13}{|c|}{ Variance Decomposition: Nigeria } \\
\hline 2 & 0.13 & 100.00 & 0.00 & 0.19 & 0.25 & 99.75 & 0.13 & 100.00 & 0.00 & 0.19 & 0.25 & 99.75 \\
\hline 3 & 0.18 & 99.99 & 0.01 & 0.26 & 0.14 & 99.86 & 0.18 & 99.99 & 0.01 & 0.26 & 0.14 & 99.86 \\
\hline 4 & 0.22 & 99.98 & 0.02 & 0.32 & 0.10 & 99.90 & 0.22 & 99.98 & 0.02 & 0.32 & 0.10 & 99.90 \\
\hline 12 & 0.26 & 99.97 & 0.03 & 0.36 & 0.08 & 99.92 & 0.26 & 99.97 & 0.03 & 0.36 & 0.08 & 99.92 \\
\hline 16 & 0.43 & 99.72 & 0.28 & 0.56 & 0.09 & 99.91 & 0.43 & 99.72 & 0.28 & 0.56 & 0.09 & 99.91 \\
\hline 24 & 0.49 & 99.54 & 0.46 & 0.62 & 0.13 & 99.87 & 0.49 & 99.54 & 0.46 & 0.62 & 0.13 & 99.87 \\
\hline
\end{tabular}


Table 13 Variance Decomposition

\begin{tabular}{|c|c|c|c|c|c|c|c|c|c|c|c|c|}
\hline \multicolumn{7}{|c|}{ High Regime } & \multicolumn{6}{|c|}{ Low regime } \\
\hline \multicolumn{4}{|c|}{ Variance EXC due: } & \multicolumn{3}{|c|}{$\begin{array}{l}\text { Variance of RES due } \\
\text { to: }\end{array}$} & \multicolumn{3}{|c|}{ Variance EXC due: } & \multicolumn{3}{|c|}{$\begin{array}{l}\text { Variance of RES due } \\
\text { to: }\end{array}$} \\
\hline Step & Std Error & $\mathrm{EXC}$ & Res & Std Error & Exc & Res & Std Error & $\mathrm{EXC}$ & Res & Std Error & Exc & Res \\
\hline \multicolumn{13}{|c|}{ Variance Decomposition: South Africa } \\
\hline 1 & 0.02 & 100.00 & 0.00 & 0.09 & 1.03 & 98.97 & 0.02 & 100.00 & 0.00 & 0.09 & 1.03 & 98.97 \\
\hline 2 & 0.02 & 99.70 & 0.30 & 0.12 & 1.16 & 98.84 & 0.02 & 99.70 & 0.30 & 0.12 & 1.16 & 98.84 \\
\hline 3 & 0.03 & 98.26 & 1.74 & 0.15 & 1.23 & 98.77 & 0.03 & 98.26 & 1.74 & 0.15 & 1.23 & 98.77 \\
\hline 4 & 0.04 & 95.81 & 4.19 & 0.17 & 1.29 & 98.71 & 0.04 & 95.81 & 4.19 & 0.17 & 1.29 & 98.71 \\
\hline 12 & 0.07 & 65.16 & 34.84 & 0.25 & 1.60 & 98.40 & 0.07 & 65.16 & 34.84 & 0.25 & 1.60 & 98.40 \\
\hline 16 & 0.09 & 53.17 & 46.83 & 0.28 & 1.74 & 98.26 & 0.09 & 53.17 & 46.83 & 0.28 & 1.74 & 98.26 \\
\hline 24 & 0.13 & 38.28 & 61.72 & 0.30 & 1.99 & 98.01 & 0.13 & 38.28 & 61.72 & 0.30 & 1.99 & 98.01 \\
\hline \multicolumn{13}{|c|}{ Variance Decomposition: Uganda } \\
\hline 2 & 0.05 & 100.00 & 0.00 & 0.10 & 0.74 & 99.26 & 0.05 & 100.00 & 0.00 & 0.10 & 0.74 & 99.26 \\
\hline 3 & 0.07 & 99.99 & 0.01 & 0.14 & 0.42 & 99.58 & 0.07 & 99.99 & 0.01 & 0.14 & 0.42 & 99.58 \\
\hline 4 & 0.09 & 99.99 & 0.01 & 0.16 & 0.32 & 99.68 & 0.09 & 99.99 & 0.01 & 0.16 & 0.32 & 99.68 \\
\hline 12 & 0.10 & 99.99 & 0.01 & 0.18 & 0.27 & 99.73 & 0.10 & 99.99 & 0.01 & 0.18 & 0.27 & 99.73 \\
\hline 16 & 0.17 & 99.99 & 0.01 & 0.27 & 0.30 & 99.70 & 0.17 & 99.99 & 0.01 & 0.27 & 0.30 & 99.70 \\
\hline 24 & 0.19 & 99.99 & 0.01 & 0.30 & 0.40 & 99.60 & 0.19 & 99.99 & 0.01 & 0.33 & 0.69 & 99.31 \\
\hline
\end{tabular}

The variance decomposition profiles are reported in Tables 11, 12, and 13. Results for Algeria show that variations in exchange rates are explained by exchange rates itself but fluctuations in reserves are contributed by exchange rate volatility where about $24 \%$ of reserve changes are explained by the changes in exchange rates by the 24th month in the high regime. Changes of exchange rates were marginally contributed by in reserves, about $3 \%$ in the low regime. But reserve volatility is generally explained by fluctuations in itself.

Results for Botswana indicate that exchange rate variations are due to changes in reserves in the high regime where almost $70 \%$ of that volatility was due to changes in reserves. However, changes in reserves were generally due to fluctuations in the reserve itself. Similarly, variations of the series in the low regime are explained by fluctuations in the series themselves. Variance decomposition for Ghana show that exchange rate variations are marginally explained by reserve volatility, about $3 \%$ by the end of the second year in the high regime. Reserve changes played a higher role in exchange rate variations in the low regime, about $14 \%$ of such changes are due to reserve variations. Morocco's results indicate that percentage of each of the series contribution to the variation of each other is very minimal in both regimes.

Kenya's variance decomposition indicate that reserve fluctuations are responsible for about $5 \%$ exchange rate changes in the high regime by 24 th month whereas exchange rates played a less important role in reserve fluctuations. Results for the low regime are similar. Both exchange rate and reserve fluctuations played very little role in each other's volatility in Nigeria for both low and high regimes. South Africa recorded contrast results where reserves have contributed hugely, over $60 \%$, to exchange rate 
variation in the high regime. However, exchange rates' contribution to reserve changes has been very little. Results for the low regime is consistent with those of the high regime. Uganda's reserve accounted for only about $1 \%$ of fluctuations in exchange rates in both high and low regimes. Similar pattern is recorded for exchange rates' role in reserve fluctuations in both regimes.

\section{Conclusions}

In this paper we have re-visited the fear of floating hypothesis for eight African countries, using both descriptive statistical techniques and more formal non-linear VAR methods. We find evidence of some continued fear of floating, but since 2000 there seems to have been less volatile movements in the US dollar which has perhaps been reflected in smaller exchange rates in some of our African countries. For example, Calvo and Reinhart (2002) report that for the US dollar there was a 59\% probability that the monthly change fells within the plus/minus $2.5 \%$ band, but in this sample, it is nearer a $95 \%$ probability. That said we have found evidence of a negative relationship between exchange rate changes and reserve changes at both the descriptive level and from the threshold VAR analysis. This suggests that there is some evidence of the fear of floating, but as countries have become more used to floating exchange rates they have perhaps also less fear of floating and do not undertake drastic action on either interest rate policy or reserve policy to protect their exchange rates.

The results also show that most of the fear of floating are found in the high regimes, an indication that availability of reserve is critical for fear of floating. Therefore, as the sample countries covered in the study depend on a few commodities for their foreign exchange earnings, the analysis highlights the importance of diversifying sources of the foreign reserves. This will reduce the level of foreign interventions in the markets and promote credibility of the monetary authorities.

Further research could usefully focus on the role of a more internationally stable US dollar as well as commodity prices on developing countries 'fear of floating' type behaviour.

Acknowledgements We are grateful to the editor, Ansgar Belke, and two anonymous reviewers for their constructive and useful comments.

Open Access This article is distributed under the terms of the Creative Commons Attribution 4.0 International License (http://creativecommons.org/licenses/by/4.0/), which permits unrestricted use, distribution, and reproduction in any medium, provided you give appropriate credit to the original author(s) and the source, provide a link to the Creative Commons license, and indicate if changes were made.

\section{References}

Ahmad AH, Harvey DI, Pentecost EJ (2011) Exchange rate regime verification: An alternative method of testing for regime changes. Economics Letters 113(1):96-98

Ahmad, A. H., Martin, C., \& Milas, C. (2014). The Policy Window: The Impact of Financial Stress in the UK. (Bath economics research working papers; No. 17/14). Bath, UK: Department of Economics, University of Bath

Balke NS, Fomby TB (1997) (1997). 'threshold cointegration`. Int Econ Rev 38(3):627-645 
Bleaney, M.F. and M. Tian (2014), Classifying exchange rate regimes by regression methods, University of Nottingham School of Economics Discussion Paper no 14/02

Calvo GA, Reinhart CM (2002) Fear of floating. Q J Econ 117(2):379-408

Çatik AN, Martin C (2012) Macroeconomic transitions and the transmission mechanism: evidence from Turkey. Econ Model 29(4):1440-1449

Chandavarkar A (1996) Central banking in developing countries. Palgrave, London

Christensen, B. V. (2016), Challenges of low commodity prices for Africa, BIS Papers, No 87

Coulibaly, B. S., Dhruv Gandhi, and Lemma Senbet (2019) Looming debt crisis in Africa: myth or reality? Brookings, April 5, 2019

Deaton, A. (1999) Commodity Prices and Growth in Africa, Journal of Economic Perspectives-Volume 13, Number 3-Summer 1999-Pages 23-40

Financial Time (2018). African nations' borrowing costs hit post write-off high. [online] Available at: https://www.ft.com/content/2a2b402c-c7b4-11e8-ba8f-ee390057b8c9 [Accessed 5 May 2019]

Frankel JA, Fajnzylber E, Schmukler SL, Servén L (2001) Verifying exchange rate regimes. J Dev Econ 66(2): 351-386

Guimarraes, R. F. and Cem Karacadag (2004), 'The empirics of foreign exchange intervention in emerging countries: the case of Mexico and Turkey', IMF Working Paper No WP/04/123

Harvey DI, Leybourne SJ, Taylor AMR (2006) Modified tests for a change in persistence. J Econ 134: 441-469

International Monetary Fund Annual Report (2001) Making the global economy work for all, Washington: USA

Jeanne and Ranciere 2006, The optimal level of international reserves for emerging market economies, IMF: WP/06/229

Killeen WP, Lyons RK, Moore MJ (2006) Fixed versus flexible: Lessons from EMS order flow. J Int Money Financ 25(4):551-579

Levy-Yeyati E, Sturzenegger F (2004) 'classifying exchange rate regimes: deeds vs words. Eur Econ Rev 49(6):1603-1635

Montes GC, Ferreira CF (2019) Effect of monetary policy credibility on the fear of floating: evidence from Brazil. J Policy Model 2019

Neely CJ (2007) Central Bank authorities' beliefs about foreign exchange intervention. J Int Money Financ 27(1): $1-25$

Nogueira, R. P. and Miguel A. León-Ledesma, (2009) Fear of floating in Brazil: did inflation targeting matter? N Am J Econ Financ, 20, Issue 3, Pages 255-266

Onyekwena, C. and Mma Amara Ekeruche (2019) Is a debt crisis looming in Africa? Brookings, April 10, 2019 edition

Pesaran MH, Shin Y (1998) Generalized impulse response analysis in linear multivariate models. Econ Lett 58:17-29

Taylor D (1981) Official intervention in the foreign exchange market or bet against the central Bank. J Polit Econ 90:256-268

The Economist (2009) Fear of Floating, 13 th June 2009 edition

Tsay RS (1998) Testing and modelling multivariate threshold models. J Am Stat Assoc 93:231-240

Publisher's Note Springer Nature remains neutral with regard to jurisdictional claims in published maps and institutional affiliations. 